\title{
ESEJI
}

TOMISLAV SUNIĆ

Profesor, University of California

Santa Barbara, California, USA

\section{NOVA EUROPSKA DESNICA}

$\mathrm{Na}$ ideološkoj bojišnici sedamdesete godine 20. stoljeća slavljene su kao doba konzervativne revolucije. U Americi i Europi određeni broj intelektualaca počeo je upozoravati ne samo na zlo komunizma nego i na opasnost od egalitarizma, prevlasti države i „pobune masa“, kao i na rastuću društvenu jednoobraznost liberalnih društava. Mnogobrojni konzervativni autori krenuli su tako daleko da su se i javno odrekli suvremenih liberalnih društava, zbog njihova navodnog skretanja prema „mekom“ totalitarizmu. Ideje i teorije koje su nakon Drugoga svjetskog rata završile u zapećku ili su se činile odbačene, odjednom su ponovno zadobile popularnost $u$ intelektualnim krugovima. Od kraja 1970-ih na one koji su sami sebe nazvali „desničarima“, i izražavali nezadovoljstvo liberalnom demokracijom, više se nije gledalo s prijezirom ili zabrinutošću. Štoviše, u nekim akademskim krugovima ideje onih koji su se prozvali „desničarima“ ili konzervativcima često su nailazile na značajno poštovanje i naklonost.

Prije svega toga treba razriješiti jedan konceptualni i semantički problem. Naziv „Europska nova desnica“ više se primjenjuje kao praktičan nego kao službeni naziv za posebnu skupinu konzervativnih autora. Autori koji se predstavljaju kao članovi takozvane Europske nove desnice, ili se vezuju uz njezine ideje, zapravo idu putem koji se oslanja na intelektualnu i filozofsku ostavštinu ranijih europskih konzervativaca, kao što su Vilfredo Pareto, Carl Schmitt, Oswald Spengler i mnogi drugi.

Zatim treba reći da pisci Nove desnice ne žele da ih se označava kao „konzervativce“ ili „desničare“, a još manje kao „fašiste“, iako ih tako zovu njihovi ideološki protivnici i klevetnici. ${ }^{1}$ Nepotrebno je navoditi da pojmovi kao što su ,staljinist", „fašist" $i$,nacist" $i$ danas imaju snažan emocionalni naboj, a njihovo pogrešno korištenje iskrivljuje dobru društvenu raščlambu. Koliko su samo puta neki ljevičarski intelektualci konzervativne političare u Americi i Europi nazvali „fašistima“? Isto tako, toliko puta smo slušali kako neki istočnoeuropski

${ }^{1}$ Pišući knjigu Europska nova desnica, korijeni ideje $i$ mislioc, (Zagreb 2009) čak sam razmišljao da se ne koristim pojmom „Nova desnica“ $i$ umjesto njega upotrijebim pojam „Europski ljevičarski konzervativci“, što bi moglo biti opravdano ako se u obzir uzme činjenica da autori i teorije koje će biti predstavljene u ovoj knjizi često obuhvaćaju ostavštinu kako europske ljevice, tako i krajnje desnice. 
emigranti i protukomunisti Staljina i Brežnjeva označuju kao „crvene fašističke vođe“. Ako i ostavimo po strani etiketiranje koje je samo sebi svrha, jedna je stvar sigurna, predstavnici nove europske desenice kritični su prema socijalizmu, liberalizmu i različitim drugim oblicima egalitarnih uvjerenja, uključujući i judeokršćanske temelje suvremene demokracije.

Prema mišljenju Nove desnice razlika između liberalizma, socijalizma i komunizma je gotovo zanemariva jer sve spomenute ideologije počivaju na premisama univerzalizma, egalitarizma te na vjerovanju u gospodarski napredak. U opisu socijalizma i liberalizma posotoji skupina konzervativnih autora koji službeno i „,neslužbeno“ ulaze u kategoriju konzervativne, protuegalitarne, protukapitalističke i protukomunističke intelektualne tradicije. Također, ti autori su jednoglasni u stajalištu da su moderna masovna društva jednaka totalitarizmu. Neki čitatelji mogu prigovoriti jednostranosti ovakvog pristupa i vjerojatno će me optužiti da djelomice zanemarujem ideje onih konzervativnih autora koji su više naklonjeni klasičnom liberalnom tumačenju jednakosti.

Zašto se Nova desnica pribojava da nenadzirana jednakost vodi u totalitarizam? Zašto Nova desnica drži da su prava nacija i zajednica važnija od univerzalnih ljudskih prava? To su samo neka od pitanja koja ćemo postaviti na idućim stranicama i na koja autori Nove desnice daju svoj jedinstveni odgovor. ${ }^{2}$ Kao što ćemo ubrzo vidjeti, u medijima i akademskim krugovima bilo je pogrešnih pretpostavki, posebice u Americi i Engleskoj, da je Europska nova desnica samo još jedna inačica suvremenoga europskog neokonzervatizma. U ovu raspravu unesena je i ideološka dimenzija. Ova dimenzija bila je u određenoj mjeri zapostavljena u proučavanju političkih pokreta i stranaka u Europi.

Znatna razina dvosmislenosti još uvijek je prisutna kada se govori o pojmu i načelu „desnice“. Tko pripada desnici i kako se, kao takav, očituje tijekom različitih povijesnih razdoblja? Ne bi li bilo primjerenije pisati o mnoštvu različitih desnica i desničarskih pokreta? „Desničari“ su stereotipno najčešće povezani s nekoliko figura, kao što su zemljoposjednik, trbušasti bankar, odvratni financijski mešetar, beznadno primitivni seljak ili sarkastični svećenik. No, što te različite ljude povezuje? Zašto svi oni glasuju za neku desničarsku stranku ili se pridružuju nekom desničarskom pokretu? Što se više stereotipni prikaz desničara suzuje, to više stereotip postaje maglovit i njegova izvanjska slika se raspada. Ako se današnji europski desničarski pokreti čine tako nekoherentnima i međusobno nepovezanima, to je zbog različitih povijesnih iskustava. Danas postoji liberalna desnica koja je iskreno odana parlamentarnim ustanovama i suprotstavlja se svim desnim pokretima koji te ustanove ugrožavaju. No, isto tako postoji i desnica ko-

${ }^{2}$ Koliko mi je poznato, postoji određen broj knjiga koje se bave Novom desnicom, iako se niti jedna od njih ne bavi Europskom novom desnicom i njezinom kulturnom i političkom posebnošću Na primjer: Desmond S. King, The New Right, The Dorsey Press, Chicago 1987. U tom djelu raščlanjuje se pristup neokonzervativaca prema „državi blagostanja“ u Europi. Također vidjeti: Alexander Yanev, The Russian New Right, University of California, Berkley 1978. U ovom djelu pisac prikazuje ruski nacionalizam u Sovjetskom Savezu i među ruskim emigrantima. 
ja je tradicionalno kršila pravila parlamentarnog sustava, čak i kada je tvrdoglavo nastojala izboriti svoje mjesto u parlamentu. Također postoji i desnica koja slavi nacionalizam i suprotstavlja se internacionalističkim doktrinama. Konačno, postoji i Europska nova desnica koja se ne zalaže ni za što od navedenog, ali koja je ipak iz svih spomenutih težnji ponešto preuzela.

Kako piše Jean-Christian Petitfils: „U našem političkom rječniku malo je pojmova koji su bili toliko obezvrijeđeni i toliko puta ispunjeni negativnim sadržajem kao što je slučaj s pojmom 'desnica'. U mjeri u kojoj se pridjev 'ljevičarski' čini laskavim, pridjev 'desničarski' koristi se kao potvora. "3 Ovaj navod može poslužiti kao korisna smjernica kako bi se pokazali nedostaci političke terminologije povezane sa suvremenim desničarskim pokretima i ideologijama. Jasno je da nisu slučajne ni teškoće u primjeni nekoga novog nazivlja. Dugo vremena nakon Drugoga svjetskog rata politički život u Europi bio je sažeto opisivan kao postojanje dvaju suprotstavljenih ideoloških tabora, ,ljevice“ nasuprot „,desnici“. Iako je ova suprotnost i dalje glavni čimbenik u određivanju izbora glasača, njezina društvena važnost ne prikazuje uvijek objektivno različite ideološke promjene do kojih je nedavno došlo u suvremenoj Europi. Ideološka crta razdvajanja koja je razlikovala ljevicu od desnice naglo se pomaknula nakon Drugoga svjetskog rata pa su na površinu političke borbe izbila potpuno nova društvena pitanja. Kako se mijenjao duh vremena, tako su se mijenjali i razlozi političkog sukobljavanja. Nema nikakve dvojbe da se u razdoblju nakon Drugoga svjetskog rata većina intelektualaca stavila na stranu ljevice. Na kraju krajeva, tko je uopće želio biti povezan s konzervativnim ideologijama koje su često, barem u političkom rječniku ljevice, podsjećale na fašističko razdoblje? Politički dualizam koji je prevladavao tijekom 1940-ih i 1950-ih, zaoštren ranijim iskustvom fašizma, potaknuo je mnogobrojne intelektualce da sve one koji su ostali na strani desnice označe kao „mračne snage reakcije koje se bore protiv uzvišenih načela napretka“. Očito je da su se u takvim okolnostima oni koji su ostali vjerni konzervativnim idejama morali prilagoditi novim intelektualnim okolnostima, u strahu da će u protivnom biti izopćeni kao suradnici fašizma. Teško je poreći da je, unatoč prevladavajućem konzervativnom institucionalnom okviru europskih društava, glavni ton kulturnom životu nakon Drugoga svjetskog rata nametala ljevičarska inteligencija. Štoviše, ljevičarska inteligencija često je protiv svojih konzervativnih protivnika primjenjivala ista sredstva koja je i sama trpjela i osuđivala prije Drugoga svjetskog rata i tijekom tog rata. Ljevičarska inteligencija tvrdila je da je u ime demokracije potrebno onemogućiti desničarske pokrete. Do koje je razine ljevičarska inteligencija sama vjerovala u demokraciju, i koju joj je važnost pridavala, pripada potpuno drugoj razini problema koji izlazi iz opsega ove knjige.

Može se zaključiti da je oznaka „desnice“ oblaćena zbog onoga što se događalo tijekom Drugoga svjetskog rata, kada su se mnogi istaknuti konzerva-

\footnotetext{
${ }^{3}$ Jean-Christian Petitfils, La Droite en France de 1979 à nos jours, PUF, Pariz 1973, 5.
} 
tivci stavili na stranu fašizma ili su mu barem davali prešutnu potporu. Zato ne iznenađuje da su nakon 1945. konzervativci imali najmanje utjecaja upravo u onim europskim državama gdje su konzervativne ideje bile najutjecajnije. Razlog zbog kojeg kulturni konzervativci, uključujući Novu desnicu, danas imaju najveću intelektualnu potporu u Francuskoj, a ne u Njemačkoj, sasvim je razumljiv ako se uzme u obzir, s jedne strane, jedinstven međunarodni položaj Francuske, a s druge strane, golema povijesna hipoteka koja i dalje teško pritišće povijesnu svijest njemačkih konzervativaca.

Kako bi stvari bile jasnije, u ovoj ćemo knjizi ponekada razmotriti razlike između Europske nove desnice i takozvane američke „nove desnice“. Iako Europska nova desnica ima nekih sličnosti sa svojim američkim kolegama, u ovoj će knjizi biti prikazano da su te sličnosti zanemarive u odnosu na bitne međusobne razlike. Među američkim konzervativcima i liberalima često je slučaj da promatraju društvene fenomene u drugim državama iz vidokruga američke društvene stvarnosti i da ih po analogiji svode na američko povijesno i intelektualno iskustvo. Prikazivati „Američku novu desnicu“ kao američki ideološki ekvivalent Europske nove desnice znači prikrivati činjenicu da je jedna od ključnih postavki Europske nove desnice upravo kritika Američke nove desnice.

Čini se da danas ideje Europske nove desnice i njezinih prethodnika izazivaju znatno zanimanje među europskim konzervativcima. Te ideje i stajališta, koje bi se opravdano mogle zvati revolucionarnim i konzervativnim, modernističkim i arhaičkim, zaslužuju punu pozornost i blagonaklono razumijevanje. Moj rad, želi predstaviti političku važnost Nove desnice za suvremenu Europu.

\section{Pojava nove desnice}

Dvadeseto stoljeće nije bilo obilježeno isključivo inflacijom političkih pokreta, nego i inflacijom u političkoj terminologiji. Pojam „Nova desnica“ prvi put su upotrijebili francuski mediji sredinom 1970-ih kako bi označili skupinu mladih francuskih intelektualaca koji su, jedno desetljeće prije, proglasili opći rat komunizmu, liberalizmu i europskoj judeokršćanskoj ostavštini. Nova desnica čini se relativno novim ideološkim i kulturnim fenomenom, ali ako se pažljivije promotri, malo je toga sasvim novo, odnosno malo je onoga što već nisu definirali prethodni konzervativni mislioci. U posljednjih stotinu godina mnogobrojni konzervativni kritičari napadali su i liberalizam i komunizam, pa bi se moglo reći da je Nova desnica zapravo stara ,antidemokratska“ desnica zaogrnuta u nešto prihvatljivije ideološko ruho. No, unatoč sličnosti s bivšom proturevolucionarnom desnicom, Nova desnica ipak predstavlja novi pokret, ako se uzme u obzir da su njezini simpatizeri i članovi uglavnom mlađi ljudi koji se suočavaju s društvenim problemima koji su prije bili nepoznati europskom iskustvu. Nova desnica je „nova“ i po tome što tvrdi da je izvršila korjenit raskid sa svim krajnje desničarskim pokretima i strankama. Također, za razliku od drugih desničara, Nova desnica ne tvrdi da ima duhovne korijene isključivo u jednoj od europskih 
država. Naprotiv, Nova desnica proklamira da je cijeli europski kontinent njezina domovina.

Kada je sredinom 1970-ih Nova desnica objavila svoj službeni ulazak na europsku kulturnu i političku scenu, izbor trenutka u kojem je to učinjeno nije bio slučajan. Nekoliko godina prije započelo je tiho ideološko preslagivanje u Francuskoj i drugim državama Europe. Znatan broj nekadašnjih ljevičarskih, socijalističkih intelektualaca prestao je napadati kapitalizam i Sjedinjene Američke Države. Umjesto toga postali su gorljivi u svojoj potpori NATO-savezu i američkome križarskom pohodu za ljudska prava. Bivši ljevičarski ,romantičari“, ako se poslužimo izrazom koji je upotrijebio Schmitt, odjednom su postali svjesni težine života u zemljama „realnog socijalizma“. Protukomunistički disidenti poput Solženjicina i Saharova slavljeni su kao novi proroci slobode, a američki način života postao je putokaz ovome novome političkom opredjeljenju. Otprilike $u$ isto vrijeme marksističke krilatice postupno su imale sve manji politički i kulturni utjecaj na intelektualce koji su svoje djelovanje započeli nakon Drugoga svjetskog rata. Ovo se dogodilo nakon što je utjecaj marksizma već bio ograničen na nekoliko izoliranih i sve slabijih zapadnoeuropskih komunističkih partija. Može se reći da je proces intelektualnog odvajanja od marksizma u Europi znatno ubrzan novim slučajevima kršenja ljudskih prava u Sovjetskom Savezu i državama Istočne Europe. Upravo u takvome društvenom kontekstu očite „,deideologizacije“ i razočaranja marksizmom pojavljuje se Nova desnica. Odjednom su konzervativne ideje opet postale privlačne, a Sjedinjene Američke Države slavljene su kao središte svjetske demokracije. Za one koji su se izjašnjavali kao „desničari““ više nije postojala opasnost da će biti dočekani s neodobravanjem intelektualne javnosti.

Europska nova desnica, koja se također naziva GRECE (od francuskog Groupement de recherche et d'études de la civilisation européenne), označava se i kao „udruga razmišljanja s intelektualnom vokacijom“. Ciljevi kojima teži su uspostavljanje udruženja mislilaca i erudita koji dijele iste ideale, a također želi organizirati svoje članove u određen oblik organske i duhovne radne zajednice. ${ }^{4}$ Izbor kratice GRECE nije slučajan. Ta kratica istovjetna je francuskoj riječi „Grèce“, odnosno Grčka, a to znači da je dugoročan cilj Nove desnice obnova pretkršćanske i helenističke ostavštine. Kratica GRECE također pokazuje da Nova desnica svoje kulturno djelovanje ne ograničava isključivo na Francusku ili Njemačku, nego želi proširiti svoj utjecaj na sve indoeuropske narode, podjednako na Slavene, Kelte i Germane.

Kada je riječ o kulturnoj strategiji, Nova desnica u mnogobrojnim sastavnicama ima neke znakovite sličnosti s Novom ljevicom. Mnoge kritičke raščlambe Nove desnice u vezi s opasnostima masovnog društva, konzumerizma, ekonomizma, pokazuju bliskost Novoj ljevici, do točke u kojoj njihove ideološke razli-

${ }^{4}$ Jan-Claude Valla u intervjuu s Pierreom Vialom, „Une communauté de travail et de pensée“, Pour une renaissance cullurelle, urednik Pierre Vial, Copernic, Pariz 1979, 23. 
čitosti nestaju. Glavni predstavnik Nove desnice, francuski filozof Alain de Benoist, ovako objašnjava njezino ideološko stajalište:

„Osobno sam potpuno ravnodušan oko toga jesam li ili nisam na desnici. Trenutno su ideje koje Nova desnica prihvaća na desnici, ali to ne znači da su one desničarske. Mogu lako zamisliti stanja u kojima bi te ideje bile na ljevici. Razmjer moguće promjene tih ideja ovisit će isključivo o promjenama političkog okružja."

Iz navedenoga bi se moglo zaključiti kako Nova desnica nije zadovoljna kada je označavaju „desnom“. Umjesto toga, Nova desnica smatra da njezine teorije trebaju prevladati ideološke razlike, bez obzira na činjenicu da ona trenutno prihvaća ideje koje su više u skladu s konzervativnim razmišljanjima.

Postoji još jedna dvosmislenost u vezi s Novom desnicom koju bi trebalo razjasniti. Je li Nova desnica politički ili kulturni pokret, i gdje se zapravo nalazi razlika između takva dva pokreta? Općenito u Europi, a posebice u Francuskoj, čini se da su politika i kultura isprepleteni i teško se mogu razdvojiti. Značajne osobe iz kulturnog života često su igrale diskretnu, ali važnu ulogu u političkom životu i njihov utjecaj na političke procese nekada je imao veći učinak nego što je bio utjecaj na izborima državnih dužnosnika. Od De Gaullea do Mitteranda, i od Adenauera do Kohla, europski vođe često su se natjecali kako bi dobili potporu istaknutih intelektualaca. Politički opstanak njihovih vlada ovisio je o prešutnoj potpori intelektualaca koje su pažljivo odabrali. Osobe iz kulturnog i umjetničkog života, iako neprimjetne u političkom životu, koriste se ovom pogodnošću kako bi kao „sive eminencije“ utjecale na državnu politiku. Takve osobe političarima koji odlučuju daju osjećaj političke respektabilnosti, premda oni sami rijetko preuzimaju odgovornost u slučajevima kada se donesene političke odluke pokažu promašenima.

Pozivajući se na primjer Nove ljevice, mislioci Nove desnice smatraju da kultura daje dušu političkom životu. Isključivo kulturnim naporima neki politički pokret može ostvariti trajnu političku legitimnost. Treba se prisjetiti da su se i Nova ljevica i Nova desnica prvo pojavili kao kulturni pokreti. Nova ljevica imala je kulturnu dominaciju u Europi do sredine 1970-ih, ali ju je do početka 1980ih godina u određenoj mjeri izgubila. Nasuprot tome, dok je politički utjecaj Nove ljevice danas u opadanju, utjecaj Nove desnice je u porastu. Na koji način i u kojoj mjeri će Nova desnica utjecati na političke procese u Europi, i s kojim će sredstvima svoje kulturne uspjehe primijeniti u političkom životu, tek treba vidjeti.

U desetljeću u kojem se na nove političke pokrete često gleda sa strahom i sumnjom da vode $u$ totalitarizam, prikazivati Novu desnicu kao samo još jedan novi politički pokret može predstavljati dodatnu teškoću. Pojam „pokret“ implici-

\footnotetext{
${ }^{5}$ Pierre Vial, „Nouvelle Droite ou nouvelle culture“, Pour une renaissance cullurelle, 9. Nova desnica u Italiji objavljuje Diorama Letterario (Firenca), u Belgiji Vouloir, Orientations (Brabant), u Španjolskoj Fundamentos (Madrid) i u Portugalu Futuro Presente (Lisabon).
} 
ra da on ima masovnu potporu, a to se ne može reći za Novu desnicu, koja je u određenoj mjeri elitistička i okuplja uski krug mislilaca. Njezinu ulogu prije bi se moglo opisati kao „kulturnu struju mišljenja“, posebice ako se uzme u obzir da razmjerno uski krug sljedbenika Nove desnice onemogućuje njezinu usporedbu s europskim političkim strankama ili pokretima. Također, činjenica da Nova desnica ideološki raskol između ljevice i desnice smatra drugorazrednim pitanjem objašnjava zašto ju je nemoguće svrstati na ljevicu ili desnicu. Na primjer, ako se uzme u obzir da se Nova desnica suprotstavlja useljavanju stranaca, moglo bi se pomisliti da ona ima političke veze s Nacionalnim frontom u Francuskoj i drugim krajnje desnim strankama. Ova pretpostavka ne može se u potpunosti odbaciti, iako treba istaknuti da Nova desnica nije štedjela riječi kada je trebalo javno kritizirati sve ekstremno desne pokrete i stranke, uključujući francuski Nacionalni front i vođu Jean-Marie Le Pena. Nasuprot tome, Nova desnica nikada nije tajila da ima sklonost prema idejama mnogih francuskih ljevičara i socijalističkih vođa i intelektualaca s kojima, na primjer, dijeli mišljenje o Europi u kojoj neće biti blokova, odnosno o raspuštanju Zapadnog bloka. Štoviše, Nova desnica je u mnogobrojnim prigodama izrazila veliko poštovanje za one socijalističke intelektualce koji su, prema njezinu mišljenju, ostali vjerni svojim socijalističkim idealima, unatoč nedavnom zaokretu njihovih bivših drugova prema neokonzervativizmu. Kako bi se razumjela ideološka ,nestabilnost“ Nove desnice, opet se treba osvrnuti na stajalište de Benoista u kojem on naglašava da su ideje Nove desnice oblikovane kako bi se probile kroz ideološke monopole i ostale otvorene podjednako za socijalističku i desničarsku inteligenciju. Može li se iz ovoga zaključiti da se Nova desnica koristi ljevičarskom taktikom ideološke prijevare ili jednostavno novom konzervativnom strategijom političkog preživljavanja?

\section{Europska Nova desnica nasuprot američkoj desnici}

Prikaz Europske nove desnice bio bi nepotpun bez barem kratkog opisa američke konzervativne scene. Američka „nova desnica“ i američki neokonzervativci imaju program koji se trenutno povezuje s jačanjem „,moralne većine“ i s nekim bivšim liberalnim i ljevičarskim intelektualcima koji su se u međuvremenu razočarali i sada iskazuju odlučni protukomunizam, suprotstavljaju se „državi blagostanja“" i naglašavaju nužnost kapitalističkoga slobodnog tržišta. Slično heterogenosti suvremenih europskih konzervativaca, među kojima je Nova desnica samo najnovija i radikalna frakcija, tako i među suvremenim američkim konzervativcima postoji otvoren raskol. Na primjer, dok se velika većina američkih konzervativaca i neokonzervativaca slaže da treba očuvati pravo slobode govora i ustavne slobode, značajan broj konzervativaca izražava želju za ponovnom uspostavom liberalnog naslijeđa konzervativizma. Uz to, čini se da ozbiljan raskol između američke ,nove desnice“ i ,stare desnice“ ima korijene u različitim stajalištima kada je u pitanju židovstvo, Izrael i antisemitizam. Ne treba se čuditi što je određen broj dobro poznatih američkih neokonzervativaca suprotstavljen onim 
američkim konzervativcima koji su, čini se, ravnodušni prema židovskom pitanju i američkoj potpori Izraelu. Kako je objasnio jedan ugledan američki konzervativac, čini se da ovaj latentni raskol neće biti uskoro okončan:

„Ovo nesuglasje proizlazi ne samo iz trenutnih problema, nego iz povijesnih korijena neokonzervativizma i osobnoga životnog puta samih neokonzervativaca. Prije negoli su postali neokonzervativci, oni su bili židovski intelektualci i hladnoratovski liberali. Ovo i dalje na njih ima utjecaja, iako su u međuvremenu promijenili svoj položaj na političkoj sceni.“6

Također, neki američki konzervativci smatraju da su njihova uvjerenja nerazdvojiva od katoličke i protestantske vjere. Nasuprot tome nalaze se neokonzervativci koji se poistovjećuju s ,prihvaćanjem moderne među sekulariziranim židovskim intelektualcima“. 7 Kako navodi Russell Kirk, „ono što uistinu pokreće neokonzervativce, posebno Irvinga Kristola, je opstanak Izraela“. Na sličan način razmišlja i Norman Podhoretz, konzervativni intelektualac židovskog podrijetla, za koga obrana Izraela predstavlja i obranu američkih probitaka, a u konačnici i obranu cijele zapadne civilizacije. ${ }^{8}$ Iako Europska nova desnica dijeli neke ideje s američkom ,novom desnicom“ i ostalim američkim konzervativcima, pri čemu se misli na oštri protukomunizam, a u određenoj mjeri i na suprotstavljanje egalitarizmu, mora se naglasiti da se, za razliku od američkih desničara, Europska nova desnica suprotstavlja kapitalističkome slobodnom tržištu, kao i američkoj gospodarskoj i kulturnoj prevlasti u svijetu. Europska nova desnica do sada nije oblikovala vlastitu gospodarsku doktrinu, iako se može pretpostaviti da ona ima određenu naklonost prema teorijama „organskoga“ i korporativnoga gospodarstva, što su u 20. stoljeću zagovarali Othmar Spann i Leon Walras. Kako ćemo kasnije vidjeti, glavnina argumenata Nove desnice u vezi s gospodarstvom temelji se na postavci da gospodarstvo mora biti u potpunosti podređeno politici i kulturi, a ne obratno. ${ }^{9}$

Bez obzira na ove razlike, i Europska nova desnica i takozvana američka „,nova desnica“, kao čimbenici društvene promjene, pojavili su se kao posljedica intelektualnih preslojavanja koja su se dogodila sredinom 1970-ih, kako u Sjedinjenim Državama, tako i u Europi. U vezi s ovime Peter Steinfels je naveo:

„Pitanje po čemu je neokonzervativizam nov, odnosno ima li uopće u njemu ičega novog, nije trivijalno. Ono utječe na način na koji se taj fenomen proučava, odnosno kako se o njemu raspravlja. Naglašavajući svoju povezanost s tradicionalnim liberalizmom, pokušavajući se prikazati isključivo vjernim nastavljačima starih težnji i vječnih istina, neokonzervativci skreću pozornost s propitivanja svojih ideja i usmjeravaju pozornost na ideje svojih suparnika, odnosno

${ }^{6}$ Alexander Bloom, „Neoconservatives in the 1980's“, The World and I, Washington, listopad 1986, 692.

${ }^{7}$ Isto.

${ }^{8}$ Isto.

${ }^{9}$ Vidjeti, na primjer, knjigu autora Nove desnice: Guillaume Faye, Contre l'économisme: Principes d'économie politique, Le Labyrinthe, Pariz 1983. 
onih koji su navodno inovativni. S druge strane, mnogobrojni kritičari neokonzervativaca uopće nisu skloni potvrditi da takav pristup donosi išta novoga. Za kritičare neokonzervativaca riječ je zapravo o starom konzervativizmu. Ono što je novo su osobe koje zagovaraju taj novi oblik konzervativizma, odnosno njegovi glasnogovornici koji su uglavnom bivši liberali, pa čak i bivši socijalisti.“i10

Ovakav razvitak u biti je američka inačica, odnosno odjek sličnih intelektualnih tegoba koje su se dogodile u Zapadnoj Europi. Riječ je o tome da se određen broj socijalističkih i liberalnih intelektualaca počeo svrstavati oko konzervativnih ideja. Ako se sve ovo uzme u obzir, unatoč sličnostima između Europske nove desnice i europskih konzervativaca s jedne strane i američke nove desnice i američkih konzervativaca s druge strane, važno je primijetiti da su njihove međusobne ideološke razlike zapravo vrlo duboke. Često se previđa da gotovo svi europski konzervativci, uključujući i mislioce okupljene oko Nove desnice, imaju značajke koje ne postoje ni u jednom obliku američkog konzervativizma. Američki konzervativci općenito rijetko dovode u pitanje ispravnost temelja na kojima su osnovane Sjedinjene Američke Države, kao obećana zemlja koja jamči slobodu govora, slobodu sklapanja ugovora i vladavinu prava. Također, za razliku od europskih konzervativaca, američki su konzervativci tradicionalno sumnjičavi prema snažnoj državnoj vlasti. Uz to, oni smatraju da ,organska društva“, odnosno stratificirana društva poput onih u Europi, predstavljaju zapreku gospodarskom razvitku. Nasuprot tome, europski konzervativci, uključujući Europsku novu desnicu, jednoglasno se slažu oko potrebe postojanja jake državne vlasti i općenito imaju puno višu razinu nepovjerenja prema vrijednosti individualne slobode. Konačno, treba skrenuti pozornost i na nešto što američki konzervativci, ali i ukupna američka javnost, često previđaju, a to je duboko ukorijenjena skepsa, agnosticizam, a ponekad i izravni nihilizam koji postoji među europskim konzervativcima. Ovo je u oštroj suprotnosti s judeokršćanskim vjerskim uvjerenjima među mnogobrojnim američkim konzervativcima. Kako upozorava David Gress, europski konzervativci, osim u Velikoj Britaniji, povijesno su i duhovno izrazito sumnjičavi prema kapitalizmu, vjeruju u nužnost postojanja snažnog društva, a prije 1945. uopće nisu voljeli Amerikance, na njih su ,gledali kao na opasnost, sklonu izazivanju poremećaja i strani čimbenik, a osim toga Amerikanci su im se činili politički i društveno naivnima“" ${ }^{11}$ Nova desnica u svojim raspravama s europskim neokonzervativcima stalno skreće pozornost upravo na to, optužujući neokonzervativce da u politiku unose „moraliziranje“ koje je svojstveno Amerikancima. Osim neslaganja sa američkom novom desnicom u vezi s pitanjem nacionalnoga i globalnoga gospodarstva, kao i razlikama koje proizlaze iz različitoga povijesnog i kulturnog naslijeđa, postoji također i ,kontinentalna" odnosno geopolitička pukotina između američkih neokonzervativaca i

\footnotetext{
${ }^{10}$ Peter Steinfels, The Neoconservatives, Simon and Schuster, New York 1979, 2.

11 David Gress, „Conservatism in Europe and America“, The World and I, listopad 1986,678 .
} 
Europske nove desnice. Ne treba se iznenaditi da je čak i u ,europskoj“ Engleskoj utjecaj Europske nove desnice uglavnom marginalan, zbog činjenice da je Engleska imala različiti politički i intelektualni razvitak od onog u kontinentalnoj Europe. Prema mišljenju Nove desnice anglosaksonski narodi, nasuprot kontinentalnim Europljanima, nisu u stanju shvatiti važnost organskih zajednica i prednost političkih čimbenika nad gospodarskim. Pretjerani individualizam anglosaksonskih naroda i jedinstvena politička teologija ,sekulariziranog“ protestantizma tijekom vremena doveli su do podređivanja tradicionalne politike neograničenoj gospodarskoj djelatnosti. U svome eseju o demokraciji Alain de Benoist objašnjava da prava i „organska“ demokracija može postojati isključivo u društvu čiji su pripadnici razvili čvrsti osjećaj povijesne i duhovne opredijeljenosti prema svojoj zajednici. U takvome organskom društvu ustrojenom kao država, nastavlja De Benoist, zakon ne smije proizlaziti iz nekakvih apstraktnih neutemeljenih načela, nego iz duha naroda i njegovih jedinstvenih povijesnih značajki. U takvoj demokraciji osjećaj zajedništva mora bezuvjetno prevladati nad sebičnim individualnim $\mathrm{i}$ gospodarskim probicima. ${ }^{12}$ Opis takvoga organskog društva ustrojenog u državu, koje predlaže Nova desnica, zapravo je u oštroj suprotnosti s univerzalističkim i liberalnim načelima koja prihvaćaju europski i američki neokonzervativci.

Iz navedenoga se može zaključiti da američki, engleski, pa čak i europski neokonzervativci predstavljaju potpunu suprotnost onome za što se zalaže Nova desnica. Štoviše, Nova desnica ne oklijeva upozoriti na opasnost koju „,konzervativni“ anglosaksonski poredak predstavlja za tradicionalne europske zajednice. Harold Hewitson, engleski znanstvenik povezan s Novom desnicom, primjećuje da se konačni cilj liberalno-konzervativnog poretka sastoji u „osvajanju društvenog duha, koji će biti nadvladan bezglavom trkom za ostvarenjem osobnog probitka, zanemarivanjem učinaka etničke pripadnosti na vrijednosti zajednice, pa će ljudske vrline biti ugušene petljanjem intelektualaca i menadžera“. ${ }^{13}$ Iako ime europska „Nova desnica“ može upozoravati na to da ona predstavlja inačicu europskih neokonzervativaca, bilo bi pogrešno kada bi se povukla bilo kakva usporedba između Europske nove desnice i zapadnih (američkih) neokonzervativaca. Izvornost „Nove desnice“ nalazi se upravo u priznavanju etničkih i povijesnih dimenzija konzervativizma, dok moderni zapadni konzervativci tu dimenziju smatraju zanemarivom te daju naglasak univerzalističkim i transnacionalnim krilaticama. Kao što će se pokazati u idućim poglavljima u ovoj knjizi, Europska nova desnica za glavne neprijatelje Europe drži kapitalističku doktrinu individualizma i prevlast gospodarstva. Upravo su ta dva čimbenika glavna pokretačka snaga suvremenih zapadnih neokonzervativaca.

Kako, dakle, definirati Europsku novu desnicu? Je li je ona nekakva poluvjerska i polupolitička sljedba, kakvih je danas u obilju u zapadnom svijetu?

\footnotetext{
${ }^{12}$ Alain de Benoist, Les Idées à l'endroit, Libres-Hallier, Paris 1979.

${ }^{13}$ Harold T. Hewitson, „G. R.E. C.E. Right Side Up“, The Scorpion, London 1986, 28.
} 
Prijašnji opis pokazuje da društvene kategorije nisu podijeljene jasno određenim društvenim konceptima. Zato svaki znanstvenik koji proučava društvo, prije nego što počne rabiti ili zlorabiti političku terminologiju, mora svaki koncept definirati u njegovu povijesnom i društvenom kontekstu.

Nova desnica označava samu sebe kao pobunu protiv bezličnosti u politici, životu i vrijednostima. Kriza modernih društava dovela je do stalnog ,poružnjivanja“, čiji su vektori liberalizam, marksizam i ,američki način života“. Suvremene prevladavajuće ideologije, marksizam i liberalizam, od kojih je prva imala uporište u bivšem Sovjetskom Savezu, a druga u Sjedinjenim Američkim Državama, štetne su za društvenu dobrobit naroda jer svode sve aspekte života na gospodarsku korisnost i djelotvornost. Nova desnica smatra da marksizam i liberalizam sami po sebi nisu glavni neprijatelji slobode, ali zajednička uvjerenost ovih ideologija u egalitarizam to jest. Zapravo marksizam nije antiteza liberalizmu, nego predstavlja najopasniji oblik egalitarizma, a takav egalitarizam neograničeno se širi u svim društvenim porama bivšega sovjetskog društva i sadašnjega američkog društva:

„Neprijatelj se nalazi u svim onim doktrinama i praksama koje predstavljaju i utjelovljuju određeni oblik egalitarizma. Očito je među njima na prvom mjestu marksizam kao najekstremniji i najnasilniji oblik egalitarizma. Znatan utjecaj marksizma na suvremenu misao, a posebno njegov utjecaj na osobe koje će već sutra biti pozvane da donose odluke u društvu, predstavlja temeljni uzrok suvremene krize. ${ }^{\text {"114 }}$

Pogreška koju liberalni mislioci nisu u stanju uvidjeti sastoji se u tome da liberalna doktrina individualizma, ekonomizma i „potrage za srećom“ ne može predstavljati značajno oružje protiv marksizma jer liberalni intelektualci, koji osuđuju posljedice marksizma, nisu u stanju kritički raščlaniti egalitarne uzroke vlastite liberalne doktrine. Kako je napisao Jean-Claude Valla: „Njih (intelektualce) privlači marksizam jer ispred njega, pokraj njega ili nasuprot njemu nema alternative. Marksizam nitko ne želi osporiti na njegovu vlastitom terenu, a istovremeno nitko ne može osporiti njegov monopol.“" ${ }^{15}$

Prema mišljenju Nove desnice, konzervativne i neokonzervativne stranke i pokreti snose veliki dio povijesne odgovornosti za gotovo poslovičnu nepopularnost konzervativnih ideja. Neokonzervativni i tradicionalni konzervativci već su potpisali vlastitu smrtnu kaznu jer su bili žrtve povijesnih okolnosti, nisu u stanju pridobiti pristaše, a tijekom prošlost su bili upleteni u kolonijalizam, rasizam i judeokršćanski mesijanizam. Ukratko, takva „desnica“ nije u stanju zadobiti intelektualnu vjerodostojnost. Kako je napisao Michael Walker, urednik engleskog časopisa The Scorpion:

„Stara desnica, bila ona nacionalistička, nacistička, kršćanska, imperijalistička ili liberalna, sa svojim pojednostavnjenim i prividno djelotvornim rješenji-

${ }^{14}$ Jean-Claude Valla, „Une communauté de travail et de pensée“, Pour une renaissance culturelle, 31 .

${ }^{15}$ Isto, 32. 
ma za probleme koji su se pojavljivali, načinila je ove mlade ljude duboko nezadovoljnima. Krajnja desnica, koja se neprestano žali, a zapravo je monotona i potpuno predvidljiva, predstavljala je uvredu zdravom razumu."“16

U očima mislilaca i pisaca Nove desnice, tradicionalni kršćanski konzervativci načinili su više štete konzervativnoj ideji nego njihovi ideološki protivnici, ljevičarska socijalistička inteligencija. Ne iznenađuje da je nakon Drugoga svjetskog rata intelektualac ili umjetnik teško mogao biti naklonjen slabo osmišljenoj konzervativnoj doktrini koja je često podsjećala na fašizam. Nakon Drugoga svjetskog rata jedini put za nekoga tko je želio postići intelektualni ugled bio je da se pridruži socijalistima ili da prihvati prevladavajuću ideologiju liberalizma, posebice od trenutka kada je popularnost marksizma počela slabjeti. Drugim riječima, intelektualci, kako bi zadobili intelektualni ugled, morali su prije svega davati formalnu potporu dominantnim ideologijama, bez obzira na svoja osobna politička uvjerenja.

\section{Nova desnica ili fašistička desnica?}

Njezina žestoka kritika marksista, liberala, konzervativaca i neokonzervativaca u kratko vrijeme načinila je Novu desnicu omraženom kulturnom strujom u Europi. Nakon što se Nova desnica službeno pojavila u Francuskoj, ubrzo je došlo do mnogobrojnih pokušaja da se u najboljem slučaju umanji njezina važnost, a u najgorem slučaju da se obezvrijedi kao još jedno skretanje u fašizam. Sudeći prema broju objavljenih članaka, Nova desnica našla se pod unakrsnom paljbom i ljevice i desnice, i neokonzervativnih i neoliberalnih intelektualaca. No, što su napadi na Novu desnicu bili češći, ona je uspijevala pobuditi sve više intelektualnog zanimanja. Mislilac Nove desnice Pierre Vial u vezi s tim je primijetio:

„Nakon što se nisu izjašnjavali o ovoj novoj struji mišljenja koju predstavlja GRECE, njezini protivnici pokušali su je diskreditirati, do sada bez većeg uspjeha. Ovaj pokušaj temeljio se na vrlo jednostavnim metodama. Na prvom mjestu, mišljenja Nove desnice predstavljana su na iskrivljen i karikaturalan način. Na drugom mjestu, odbijala se bilo kakva rasprava ili dijalog, što je pravdano ozloglašenošću i odvratnošću Nove desnice, a takvu sliku o Novoj desnici prethodno su iscrtali upravo njezini kritičari. Na taj način pokušali su Novu desnicu obezvrijediti, a i potaknuti mržnju prema njoj. I nakon svega spomenutog, uložen je i napor kako bi se ljudi odvratili od toga da uopće čitaju ili se pozivaju na tekstove Nove desnice. “17

Kritičari Nove desnice u svakom slučaju nisu šutjeli. J. Gruenewald, urednik francuskih novina Tribune Juive, izjavio je: „Budimo ponosi pokazati

\footnotetext{
${ }^{16}$ Michael Walker, ,Spotlight on the French New Right“", The Scorpion, London 1986, 8.

${ }^{17}$ Pierre Vial, „Nouvelle Droite ou nouvelle culture“, Pour une renaissance culturelle,
} $10-11$. 
naše neprihvaćanje ove teorije (Nove desnice). “18 Francuski socijalistički dnevnik Le Matin je 31. 7. 1979. objavio: „Nemoguća je bilo kakva rasprava s ljudima i idejama čije izražavanje u demokratskom društvu uopće ne bi trebalo postojati. “19 Ipak je najoštrija osuda došla od uglednoga francuskog lista Le Nouvel Observateur, koji je na punih pet stranica iznio oštar napad na Novu desnicu, pozivajući svoje čitatelje da u vezi s njom pokažu „najveću opreznost““ ${ }^{20}$ Novinar Le Nouvel Observateura upozorio je da Nova desnica nije samo bezazlen kulturni pokret, koji se za svoje ideje želi izboriti na kulturnom planu. Naprotiv, Nova desnica predstavlja buđenje ideološkog eksperimentiranja i okupljanje ekstremne desnice. ${ }^{21} \mathrm{Za}$ Le Nouvel Observateur riječ je o jednostavnom problemu - stara fašistička desnica pojavila se u novom ruhu. Članovi Nove desnice zapravo su poznati bivši studenti koji su ranije, sredinom 1960-ih, bili uključeni u fašističke skupine koje su djelovale u Francuskoj. „Maska je pala“, piše dalje u članku, ,provedena istraživanja pokazuju da francuska desnica ide dalje i ostvaruje napredak. Ovo čini neprikriveno, iako smatra kako se ipak treba umotati u otrcani modernizam." 22

Neki novinari i pisci bili su manje otrovni u kritici Nove desnice, unatoč njihovoj vidljivoj zabrinutosti, pa i dubokom neslaganju s nekim njezinim idejama. Tako je tijekom kampanje difamacije Nove desnice dopisnik časopisa Les Nouvelles littéraires primijetio da su „ozbiljne rasprave zaobiđene nauštrb pojednostavnjenog anatemiziranja““ ${ }^{23}$ Jedan drugi dvotjednik je trezveno, ali ipak kritički napisao:

„Zadaća koju su na sebe preuzeli Alain de Benoist i Nova desnica još uvijek nas ostavlja zbunjenima. Njegova poruka istovremeno je i modernistička i arhaična, mitska i znanstvena. Ona je zato dvosmislena, unatoč svojoj jasnoći i pokušaju da političkoj (konzervativnoj) većini, koja traži bestselere, osigura vlastite 'tekliće', ali također i da uznemiri ponekog novinara Libérationa, koji se oduševljava kritikom masovnog društva i različitošću. ‘24

Ni neokonzervativci nisu bili puno naklonjeniji idejama koje je podržavala Nova desnica. Poznati kritičar i pisac Jean-François Revel, poznat po znatnom utjecaju na američke neokonzervativce, napisao je da Nova desnica predstavlja podjednaku prijetnju demokraciji kao i Nova ljevica i marksistički intelektualci. Prema njegovu mišljenju, Nova desnica se približava ,intelektualnoj nenormalnosti". 25

\footnotetext{
${ }^{18}$ Navedeno u: P. Vial, Pour une renaissance culturelle, 11.

${ }^{19}$ Isto.

${ }^{20}$ „Les habites neufs de la droite française“, Le Nouvel Observateur, Pariz, 8. 7. 1979, 33.

${ }^{21}$ Isto.

${ }^{22}$ Isto.

${ }^{23}$ Les Nouvelles littéraires, Pariz, 26. 7. 1979, citirano prema P. Vial, Pour une renais-
} sance culturelle, 12

${ }^{24}$ La Quinzaine littéraire, Pariz, „Mais qu'est-ce donc la Nouvelle droite?““, 15. 11. 1979, 8.

${ }^{25}$ Jean François Revel, Comment les démocraties finissent, Pluriel, Pariz 1983, 37-38. 
Kako se počela razvijati kontroverzija oko Nove desnice, francuski, a kasnije i svi europski mediji, koristili su svaku mogućnost kako bi kritizirali ideje koje je zastupala. Nakon prve tiskovne konferencije Nove desnice, održane 18. rujna 1979, ona je optužena da zagovara socijalni darvinizam, biološki materijalizam i rasizam. Uz to, protivnici Nove desnice organizirali su nekoliko napada na njezine prostorije i pokrenuli dobro usklađenu kampanju obezvrjeđivanja prije svakoga njezina sastanka i konferencije. Također su neke nakladničke kuće odbile objavljivati tekstove Nove desnice. ${ }^{26}$

Početkom 1980-ih medijska hajka na Novu desnicu donekle se primirila u Francuskoj, ali je ojačala u drugim dijelovima Europe, posebice u Njemačkoj, gdje je ogranak Nove desnice započeo djelovati razmjerno nedavno. Njemačka Nova desnica, koja djeluje u suradnji s konzervativnom udrugom Thule Seminar, ubrzo je trebala otrpjeti isti intelektualni ostracizam i žestoke kritike koje su doživjeli njihovi francuski kolege. U srpnju 1986. dom Wigberta Graberta, glavnog urednika Thule Seminar, u Tübingenu, bio je jako oštećen. Čini se da su to učinili ljevičarski ekstremisti. Iste godine Pierre Krebs, pisac i glavni glasnogovornik Nove desnice u Njemačkoj, postao je meta nasilnih prosvjeda i napada dok je držao predavanje na Sveučilištu u Beču. Kako je kasnije izvijestilo njemačko izdanje časopisa Nove desnice Elemente, ovi ispadi ljevičarskog ekstremizma su, ironično, zapravo postigli suprotan učinak te su dodatno naglasili ugled i važnost Nove desnice:

„Ovo je sada očigledna činjenica. Naše ideje imaju učinak. Naše ideje uznemirile su dobitnike egalitarizma, bili oni ljevičari ili desničari. Naše ideje sve više ometaju tijek događaja, jer od naših protivnika traže spremnost i snagu argumenta koju oni nemaju. Umjesto bitke na kulturnom i intelektualnom polju, koja bi zahtijevala inteligenciju, naši protivnici otvoreno pokazuju da su spremni pribjeći nasilju nakon što su iscrpili snagu svoje misli. Štoviše, ove boljševičke i plutokratske bitange služe se nasiljem bez straha da će biti kažnjeni, jer djeluju skrivajući se u noći i magli ('Nacht und Nebel')..."27

U međuvremenu Nova desnica nije imala puno uspjeha u pokušaju da poveća broj svojih pristaša među tradicionalnim europskim konzervativcima. Činjenica da je Nova desnica neprestano kritizirala NATO-savez, utjecaj Sjedinjenih Država na Europu, kao i judeokršćansku ostavštinu, činila se mnogim konzervativnim misliocima, koji su na početku bili naklonjeni Novoj desnici, neprihvatljivom u trenutku kada je Europa i dalje bila izložena prijetnji Sovjetskog bloka. Štoviše, to su smatrali znakom pokornosti pred Moskvom. Još je šokantni-

${ }^{26}$ Knjige koje su napisali autori Nove desnice prevedene su na talijanski, njemački, španjolski, nizozemski i grčki jezik. Osim nekih prikaza knjiga, članaka i reportaža koje su objavili engleski The Scorpion i američki časopisi Telos i Chronicles, američki i engleski nakladnici uglavnom su zanemarili djela Europske nove desnice.

27 „Gewalt statt Argumente gegen das Thule Seminar“, Elemente, siječanj-ožujak 1987,45 
ja bila izjava Alaina de Benoista u kojoj je naveo da komunistički totalitarizam za Europu predstavlja manju opasnost od liberalnog totalitarizma:

„Istina je da postoje dva oblika totalitarizma koja su različita u uzrocima i posljedicama, ali su podjednako opasna. Komunistički totalitarizam zatvara, progoni i ubija čovjekovo tijelo, ali ostavlja nadu. Zapadni totalitarizam stvara sretne robote. Takav totalitarizam predstavlja svojevrstan ugodan oblik pakla i u konačnici ubija dušu. ${ }^{\text {‘28 }}$

U Sjedinjenim Američkim Državama Nova desnica bila je gotovo sasvim prešućivana, iako je izazvala određenu zabrinutost među židovskim intelektualcima i nakladnicima. Zato je I. R. Barnes, stručnjak za neofašizam koji predaje u Engleskoj, u njujorškome židovskom časopisu Midstream napisao da su ,,profinjeni lavovi Nove desnice uveli novu taktiku infiltriranja i zadobivanja kulturne moći“. ${ }^{29}$ Sa znatnom razinom zabrinutosti Barnes je napao Europsku novu desnicu kao antisemitsku i pronacističku organizaciju. Smatrao je da Nova desnica na kulturnom planu promiče fašističke i neofašističke ideje, pokušavajući normalizirati fašizam među intelektualnom elitom. ${ }^{30}$

Nakon nekoliko godina tijekom kojih nije bilo nikakvih događaja povezanih s Europskom novom desnicom, 1987. u američkom konzervativnom tisku započela je nova kontroverzija, ovaj put u časopisu World and I. Ovaj časopis izdavala je nakladnička kuća Washington Times Corporation, koju je financirao korejski tajkun Sun Myung Moon. U spomenutom časopisu znanstvenik David Gress s Hoover Institute prikazao je De Benoistovu knjigu Europe, Tiers Monde même combat. Gress je izrazio žaljenje što je francuska ljevica našla svoje mjesto u uglednom svijetu parlamentarne demokracije, dok „Alain de Benoist, koji se nekada s ponosom zvao desničarom, sada prihvaća odbačene ljevičarske ideje“". ${ }^{31}$ Ovo se jasno odnosilo na činjenicu da je De Benoist često hvalio Régisa Debraya, Antonija Gramscija i druge socijalističke „metapolitičare“. Gress je napisao da ,čovjek poput de Benoista, koji prije nije bio u pravu, ali je barem bio zanimljiv, sada podržava ove štetne i iskvarene ideologije, a čineći to uspio je postati i opasan i glup“. ${ }^{32} \mathrm{U}$ istom broju časopisa World and I pisao je i Thomas Molnar, američki katolički filozof podrijetlom iz Mađarske i De Benoistov prijatelj. I on je komentirao njegovu knjigu, braneći Europsku novu desnicu i zalažući se za nacionalnu samostalnost europskih naroda, kao i naroda Trećeg svijeta:

${ }^{28}$ Ovo je poznata izjava Alaina de Benoista, glavnog filozofa Europske nove desnice, navedena u pariškom Le Monde od 28. svibnja 1981, a i kasnije ju je de Benoist često koristio, npr. u svojoj knjizi Europe, Tiers monde même combat, Robert Laffont, Pariz 1986, 219.

${ }^{29}$ I. R. Barnes, „Creeping Racism and Anti-Semitism“, Midstream, New York, veljača $1984,14$.

${ }^{30}$ Isto, 13.

31 David Gress, „From the Right to the Left“, The World and I, Washington, svibanj 1987,437

${ }^{32}$ Isto, 439. 
„Unatoč pojednostavnjivanju njegovih teza, šteta je što de Benoistova kritika ne nailazi na ozbiljan odjek u Americi. Mi smo zadovolji s našom 'čistom savješću', a one koji je dovode u pitanje smatramo primitivcima ili ljubomornim osobama. Odbijamo uzeti u razmatranje mišljenje da američki materijalizam može nanijeti štete drugima. “33

Beskompromisni napad Nove desnice na američke multinacionalne tvrtke i američku diplomatsku i vojnu prisutnost $\mathrm{u}$ Trećem svijetu potaknuli su Rogera Kaplana, pomoćnika urednika Reader's Digesta, da optuži A. de Benoista za antiamerikanizam. Kaplan je pisao da „on (de Benoist) ne voli kapitalizam, pa zato olako prihvaća potpuno nepotvrđenu tvrdnju da su kapitalizmu nužne kolonije, odnosno, ukratko da kapitalizam neizbježno znači imperijalizam“ “. ${ }^{34}$ Pokazujući očiglednu nesklonost prema zalaganju Nove desnice za ujedinjenom i snažnom Europom, Kaplan je dalje napisao: „Europa, što je to? San Karla Velikog ili san Adolfa Hitlera? Europa je svijetu dala 2000 godina pokolja i nereda, a oni od nas očekuju da vjerujemo da će od sada Europa biti područje ljubavi i suradnje.“" ${ }^{\text {35 }}$

Povoljni komentari o Novoj desnici, a posebno o De Benoistovoj erudiciji, došli su od Paula Gottfrieda, bivšeg urednika časopisa The World and I. Komentirajući zajedničku knjigu Molnara i De Benoista $L$ 'éclipse du sacré, u kojoj su ova dva autora, svaki sa svoje strane, branili monoteistički, odnosno politeistički svjetonazor, Gottfried je napisao da su „u međusobnom sukobljavanju pokazali zavidnu razinu erudicije, koju su ostvarili čitajući cijeli svoj život. Za razliku od većine američkih intelektualaca, oni vjeruju da su duhovna pitanja važnija od javne politike. Iskazujem poštovanje obojici sudionika ove debate i pohvaljujem ih što raspravljaju o stvarima koje imaju trajnu vrijednost" ${ }^{36}$

Neke europske novine i časopisi bili su naklonjeniji kulturnim naporima Nove desnice, posebice tjedni prilog Le Figaro Magazine. Objavljivanje Le Figaro Magazine započelo je 1978, a do kraja 1979. ova tiskovina mogla se pohvaliti da ima publiku od više od pola milijuna čitatelja, što je bilo bez premca u dotadašnjem francuskom novinstvu. Le Figaro Magazine vodio je Louis Pauwels, konzervativni intelektualac i pisac koji je bio u dobrim odnosima s Novom desnicom. On je mladim piscima Nove desnice dao mogućnost da pišu u njegovu glasilu, čime su njihove ideje postale pristupačnije široj javnosti u Francuskoj. Da nije bilo Louisa Pauwelsa i Le Figaro Magazine, mladi pisci Europske nove desnice posve sigurno bi puno teže dosegnuli više razine francuskoga kulturnog ži-

33 Thomas Molnar, „American Culture: A Possible Threat“, The World and I, maj 1987,442

${ }^{34}$ Roger Kaplan, „The Imaginary Third World and the Real United States“, The World and I, maj 1987, 446.

${ }^{35}$ Isto.

${ }^{36}$ Vidjeti prikaz djela L'éclipse du sacré koji je napisao Paul Gottfried u: The World and I, decembar 1986, 450-453. 
vota. ${ }^{37}$ Još jedan časopis koji je pokazao zanimanje za ideje Nove desnice bio je i Contrepoint, koji je izlazio mjesečno i koji je uređivao poznati francuski intelektualac Yvan Blot. Contrepoint je okupljao ugledne konzervativne intelektualce koji su pripadali podjednako prestižnom Clubu d'Horologe, okupljalištu konzervativnih umjetničkih i kulturnih mislilaca, koji su poznati po svojim vezama $\mathrm{s}$ francuskim konzervativnim političarima. Ipak, u posljednjim godinama konzervativni intelektualci iz Cluba d'Horologe pokazuju manje zanimanja za ideje koje zastupa Nova desnica. Može se pretpostaviti da je razlog za to antiamerikanizam Nove desnice, kao i njezino zalaganje za vjerski politeizam.

Još jedna povoljna primjedba o Novoj desnici došla je od Armina Mohlera, poznatoga njemačkog istraživača suvremene europske povijesti. U eseju ,Wir feinen Konservativen" on zastupa stajalište da kampanja difamacije koju su protiv Nove desnice pokrenuli francuski mediji podsjeća na „lov na vještice“ koji je u Zapadnoj Njemačkoj protiv konzervativnog povjesničara Helmuta Diwalda pokrenuo tjednik Der Spiegel. Mohler primjećuje da je liberalnim medijima bilo vrlo teško diskvalificirati Novu desnicu izjednačavajući je s nacistima, jer su autori okupljeni oko Nove desnice po svojim godinama u potpunosti odvojeni od nacističkog, odnosno fašističkog razdoblja. ${ }^{38}$ Mohler također primjećuje da su najoštriji kritičari Nove desnice upravo osobe s nacističkom odnosno fašističkom prošlošću, koji su se kasnije pokajali, kao novinar Der Spiegela Georg Wolf ili ,,politolog Maurice Duverger, koji je svoju političku karijeru započeo kao pristaša francuskoga fašističkog vođe Jacquesa Doriota“. ${ }^{39}$ Istovremeno, Mohler pozdravlja kulturnu i intelektualnu posebnost Nove desnice i dodaje da „mladi Francuzi Nove desnice mogu slobodno širiti svoj misaoni obzor, jer im je njihov nacionalni identitet samorazumljiv. Za razliku od njih, njemački konzervativci u razdoblju nakon Drugoga svjetskog rata smatraju mudrim da svoje nacionalno pitanje prepuste drugima“" 40

Danas je Nova desnica aktivna u svim dijelovima Europe, iako je zbog navedenih razloga njezin utjecaj najveći u Francuskoj. Pisci okupljeni oko Nove desnice održavaju redovite konferencije u Parizu i drugdje u Europi. Na konferencijama se bave različitim temama koje se kreću od društvene biologije do metafizike i od medicine do antropologije. Važno je spomenuti da osim čvrste jezgre Nove desnice, koja je brojčano prilično ograničena, Nova desnica ima i znatnu intelektualnu potporu uglednih članova akademske zajednice i nekih

${ }^{37}$ Bivši urednik Le Figaro Magazine Louis Pauwels se kasnije vidljivo udaljio od Nove desnice, iako i dalje priznaje njezinu veliku kulturnu vrijednost. Pauwels je izjavio: ,Ne žalim što sam tijekom 1970-ih pomogao širenju kruga koji je pratio djelovanje Nove desnice. No, njezin kasniji razvitak, kao i tijek moga života, udaljili su nas. No, svaki će pošteni povjesničar jednoga dana morati priznati da je škola mišljenja koju je pokrenuo Alain de Benoist igrala ključnu ulogu u raspadu ljevičarske doktrine i obnovi kulturne moći desnice." Navedeno prema: Eléments, 1985, 38.

38 Armin Mohler, Vergangenheitsbewältigung, oder wie man der Krieg nochmals verliert, Sinus Verlag, Krefeld 1980, 92.

\footnotetext{
${ }^{39}$ Isto.

${ }^{40}$ Isto, 97.
} 
svjetski poznatih znanstvenika. Ipak, ta je potpora zbog mnogih razloga često prešutna. Članovi akademske zajednice, poput spomenutog znanstvenika Armina Mohlera, psihijatra H. J. Eysencka, filozofa Juliena Freunda, kao i mnogih drugih manje poznatih, redovito posjećuju seminare i konferencije koje organizira Nova desnica, tijekom kojih kritički raščlanjuju uzroke suvremene krize.

Nova desnica, ili GRECE, koja je počela takoreći ni iz čega i koja je neprestano bila meta intelektualnog ostracizma i kritika, ipak je uspjela stvoriti znatnu intelektualnu potporu, posebice među visokom inteligencijom u Europi. Ipak, treba naglasiti da se simpatizere, suradnike i članove Nove desnice ne treba promatrati kao misaoni monolit sa zajedničkim političkim programom. Do sada je glavni cilj Nove desnice bio ponovno okupiti, obnoviti i oživjeti djelovanje znanstvenika, pisaca i mislilaca koji su kritični prema egalitarizmu i svim oblicima društvene jednoobraznosti.

Iz ovoga se može zaključiti da je Nova desnica postigla znatan kulturni utjecaj u Europi, posebice u visokim francuskim znanstvenim ustanovama. Jedna od primamljivih značajki Nove desnice jeste njezina otvorenost prema svim ideološkim izazovima, bili oni lijevi ili desni, fašistički ili komunistički. Takav „organski“ pristup obuhvaća ideje gotovo svih političkih strujanja i prelazi preko cijeloga društvenog spektra. Uz to, mislioci Nove desnice često su suglasni s nekim ljevičarskim intelektualcima. Nova desnica poštuje moralnost i intelektualni integritet nekih socijalističkih intelektualaca, poput Régisa Debraya. Posebice treba naglasiti kako Nova desnica ističe da je uvijek spremna pokrenuti dijalog sa svojim intelektualnim i političkim protivnicima. Njezina spremnost na raspravu također joj daje auru kulturne tolerancije, čije političke posljedice tek treba vidjeti. 